\title{
KARAKTER TOKOH PADA NOVEL "DI BAWAH LANGIT" KARYA OPICK TOMBO ATI DAN TAUFIQURRAHMAN AL-AZIZY
}

\author{
Rusmawati \\ FKIP Universitas Lambung Mangkurat \\ Rusmawati45@yahoo.com
}

\begin{abstract}
Abstrak
Latar belakang dalam pemilihan judul ini, yaitu karena isi cerita pada novel tersebut sangat berkesan sekali bagi orang yang sudah membaca novel tersebut dan banyak orang yang mengatakan bahwa novel ini sangat bagus isinya. Karakter tokoh adalah watak, sifat, dan karakter yang melekat pada diri tokoh. Karakter tokoh merupakan gambaran watak yang dimiliki tokoh dalam cerita. Karakter tokoh atau perwatakan merupakan unsur intrinsik dari sebuah novel. Objek penelitian ini berupa novel " $D i$ Bawah Langit” Karya Opick ,Tombo Ati" dan Taufiqurrahman al-Azizy. Tujuan penelitian ini mendeskripsikan karakter tokoh pada novel Di Bawah Langit Karya Opick „Tombo Ati" dan Taufiqurrahman al-Azizy.

Metode yang digunakan adalah metode deskriptif, dengan teknik pengelompokkan data yang disesuaikan dengan prinsip deskriptif, berdasarkan hasil penelitian yang diperoleh dapat disimpulkan bahwa: tokoh yang terdapat pada novel "Di Bawah Langit” karya Opick „Tombo Atie dan Taufiqurrahman al-Azizy berjumlah 18 orang. Para tokoh diklasifikasikan menjadi dua kategori yaitu tokoh protagonis dan tokoh antagonis. Karakter tokoh protagonis ada 15 orang yang terdapat pada novel Di Bawah Langit dan karakter tokoh yang antagonis ada 3 orang, Pandangan yang menggambarkan watak tokoh ada dua cara yaitu, secara analitik dan dramatik. Dramatik melalui dua cara yaitu, teknik cakap dan teknik reaksi tokoh. Berdasarkan hasil analisis di atas peneliti menyarankan bagi pembaca, dapat mengambil nilainilai positif yang terkandung pada novel tersebut.
\end{abstract}

Kata Kunci : karakter, tokoh, novel

\begin{abstract}
Figures in the novel "under the sky" by Opick 'Tombo Ati' and Taufiqurrahman alAzizy. The background of this title in the election, namely because of the content of the story at the very memorable novels for people who've read the novel and many people are saying that this novel is very good contents. Character is character, character traits, and character that rub off on figure. Character is character character description, owned the characters in the story. The character of the character or disposition is the intrinsic elements of a novel. The object of this research in the form of the novel "under the sky" by Opick 'Tombo Ati' and Taufiqurrahman al-Azizy. The purpose of this research describe the character of the character in the novel under the sky Works my 4shared' Tombo Ati ' and Taufiqurrahman al-Azizy.
\end{abstract}

The method used is descriptive method, with a customized data grouping technique with a descriptive principle, based on the research results obtained can be 
concluded that: the character in the novel "under the sky" by Opick 'Tombo Ati' and al-Azizy Taufiqurrahman totaled 18 people. The characters are classified into two categories namely the protagonist and antagonist. The character of the protagonist there 15 people found in the novel under the sky and the antagonistic character of character there are three persons, the view that depicts the characters there are two ways i.e., in analytic and dramatic. Dramatically through two ways-that is, reaction engineering and skilled engineering figures. Based on the above analysis researchers suggest to readers, can take positive values contained in the novel.

Keywords: characters, the character, the novel

\section{Pendahuluan}

Ketika membaca karya sastra seseorang akan memperoleh manfaat. Manfaat tersebut secara tidak langsung akan memberikan kesenangan dan kepuasan batin. Selin itu, manfaat yang kita peroleh tidak hanya mendapatkan sebuah kesenangan atupun kepuasan batin tetapi kita akan mendapatkan sebuah pembelajaran dalam kehidupan. Jadi, secara tidak langsung kita akan mendapatkan pengetahuan serta pembelajaran hidup melalui karya sastra baik itu berupa puisi, cerpen, novel, ataupun drama.

$$
\text { Suharianto }
$$

berpendapat "Dalam sebuah novel ada krikteria yang harus dinilai misalnya dari segi penokohan. Penokohan atau perwatakan adalah pelukisan mengenai tokoh cerita, baik keadaan lahirnya maupun keadaan batinnya yang dapat berupa padanan hidupnya, adat dan istiadatnya dan sebagainya."

Tokoh itu sangat penting dalam memainkan sebuah cerita. Melalui tokoh itulah, perwatakan manusia bisa digambarkan dengan karakter yang baik atau buruk dalam memerankan dalam sebuah cerita. Kalau tokoh tidak bisa memerankan karakternya dengan sesungguhnya dalam memainkan sebuah cerita itu maka, cerita itu tidak bisa berjalan dengan baik atau seutuhnya.
Karakter tokoh seseorang bisa dipahami melelui apa yang dipikirannya, diketahui dari perbuatannya, dan dari lukisan fisik dan latarnya. Dengan begitu, kita bisa memahami sifat karakter tokoh yang diperankan dalam memainkan sebuah cerita. Seseorang yang membaca novel dia pasti bisa mengetahui karakter tokoh yang terdapat dalam novel tersebut.

Novel sebagai karya satra dibentuk dari dua unsur intrinsik dan ekstrinsik seperti pada cerpen (pelajaran lalu). Unsur intrinsik novel tidak jauh berbeda dengan unsur intrinsik dalam cerpen yaitu; tema, alur, plot, jalan cerita, latar, setting, tokoh, pelaku cerita, karakter, watak tokoh, pesan, amanat, dan sudut pandang cerita, point of view.

Juanda dan Rosdyanto (2006: 325) berpendapat "Novel adalah karangan yang mengisahkan sisi utuh problematika kehidupan seseorang atau beberapa orang tokoh. Sementara itu cerita pendek adalah karangan pendek yang pada umumnya mengisahkan masalah yang sederhana dan diceritakan secara singkat."

Kosasih

(2003:

menyatakan "Kata novel berasal dari bahasa Italia novella berarti „sebuah barang baru yang kecil". Kemudian kata itu diartikan sebagai sebuah karya sastra dalam bentuk prosa. Novel adalah karya imajinatif yang mengisahkan sisi utuh atas 
problematika kehidupan seseorang atau beberapa orang tokoh."

Wiyatmi (2006: 30) berpendapat "Tokoh adalah para pelaku yang terdapat dalam sebuah fiksi. Tokoh dalam fiksi merupakan ciptaan pengarang, dan merupakan gambaran dari orang yang hidup di alam nyata. Oleh karena itu, dalam sebuah fiksi tokoh hendaknya dihadirkan secara alamiah."

"Penokohan merupakan salah satu unsur intrinsik karya sastra, di samping tema, plot, setting, sudut pandang, dan amanat. Penokohan adalah cara pengarang menggambarkan dan mengembangkan karakter tokoh dalam cerita" (Kosasih, 2003: 250).

Klasifikasi tokoh ada bermacam-macam berdasarkan peranan tokoh dalam cerita, terdapat tokoh sentral dan tokoh pembantu. Berdasarkan perkembangan konflik cerita terdapat tokoh protagonis merupakan tokoh yang memperjuangkan kebenaran dan kejujuran atau tingkahlaku yang dimilikinya disenangi oleh pembaca, sedangkan tokoh antagonis justru melawan kebenaran dan kejujuran atau tingkahlaku yang dimilkinya tidak disukai oleh pembaca karena perilakunya sangat kasar pada orang lain. Jenis tokoh ada dua, yaitu:

1. Analitik, yaitu pengarang langsung memaparkan tentang watak atau karakter tokoh, pengarang menyebutkan bahwa tokoh tersebut keras hati, keras kepala, penyayang, dan sebagainya.

2. Dramatik, yaitu pengarang memaparkan watak atau karakter tokoh dengan tidak diceritakan langsung, tetapi disampaikan melalui cara:

a) Pilihan nama tokoh misalnya nama Sarinen untuk pembantu, mice untuk gadis yang agak genit, bonar untuk nama tokoh garang dan gesit,

b) Melalui penggambaran fisik atau postur tubuh, cara berpakaian, tingkah laku terhadap tokoh lain, dan lingkungannya,

c) Melalui dialog watak tokoh dan cara berpikirnya dapat diamati melalui ucapannya.

Ada dua cara menggambarkan watak tokoh, yaitu secara langsung (telling analitik) dan tak langsung (showing dramatik). Selanjutnya secara tak langsung watak tokoh digambarkan melalui beberapa cara yaitu.

1. Penamaan tokoh (naming),

2. Cakapan,

3. Penggambaran pikiran tokoh,

4. Arus kesadaran,

5. perasaan tokoh,

6. Perbuatan tokoh,

7. Sikap tokoh,

8. Pandangan seorang atau banyak tokoh terhadap tokoh tertentu,

9. Pelukisan fisik, dan

10. Pelukisan latar.

Karakter itu menggambarkan sikap seseorang yang akan diperankan dalam sebuah cerita bisa berupa cerpen, novel, drama, pemain senetron, dan lain-lain. Dengan itu kita bisa menilai karakter seseorang, bukan dari segi itu saja kita bisa menilai karakter seseorang. Kita bisa menilainya dari segi dilingkungan sekitar dia tinggal.

Di dalam sebuah novel itu pasti 
ada yang namaya karakter atau watak seseorang yang menjadi sudut pandang. Pembentukan karakter dan watak atau kepribadian ini sangat penting, bahkan sangat mendesak dan mutlak adanya (tidak bisa ditawar lagi). Hal ini cukup beralasan, mengapa mutlak diperlukan karena adanya krisis yang terus berkelanjutan melanda bangsa dan negara kita sampai saat ini belum ada solusi secara jelas dan tegas, lebih banyak berupa wacana yang seolah-olah bangsa ini diajak dalam dunia mimpi.

Munir (2010: 9) berpendapat "Karakter orang pemberani akan sulit diubah menjadi penakut atau pengecut. Demikian juga karakter lembut akan sulit berubah menjadi kasar."

Karakter adalah bagian dari manusia, dari segi dalam (psikis) dan segi luarnya (jasmaniah), sehingga merupakan suatu kesatuan psikhofisis. Aspek jasmaniah menentukan karakter dan sebagai pentimbangan dari karakter dalam mengekspresikan diri. Dalam bentuk pelahiran yang sifatnya jasmaniah. Karena adanya pengaruh yang timbal balik, mengakibatkan terjadi permasalahan dalam diri setiap individu.

"Berkenaan dengan karakter tokoh yang terdapat pada novel, kalian dapat mendefinisikannya jika kalian membaca novel secara utuh dan lengkap. Selain itu, kalian juga dapat memahami unsur intrinsik yang ada." (Wirajaya dan Sudarmawati, 2008: 125).

Mustari (2011: 28) berpendapat ada beberapa karakter bangsa yang dibentuk dari watak diantaranya: disiplin, kerja keras, percaya diri, mandiri, ingin tahu, sadar diri, cerdas, suka menolong, dan lain- lain.

Ratna (dalam Minderop, 2013: 54) berpendapat "secara definitif, tujuan psikologi sastra adalah memahami aspek-aspek kejiawaan yang terkandung di dalam suatu karya... Melalui pemahaman terhadap para tokoh. Misalnya, masyarakat dapat memahami perubahan, kontradiksi, dan penyimpangan-penyimpangan lain yang terjadi di masyarakat, khususnya yang terkait dengan pisik".

Novel yang dikaji pada penelitian ini adalah novel "Di Bawah Langit" karya Opick "Tombo Ati" dan Taufiqurrahman al-Azizy. Novel ini dipilih karena berisi tentang pergolakan cinta sprituallitas Maysaroh, Gelung, dan Jaelani, serta konflik tentang hukum dan kebenaran. Betapa kesejatian cinta akan menghantar pada kebahagiaan meski diperlukan penantian yang panjang dan kesabaran yang panjang.

Berdasarkan

beberapa keterangan di atas, peneliti ingin meneliti mengenai karakter tokoh yang terdapat dalam novel Di Bawah Langit karya opick „Tombo Ati" dan Taufiqurrahman al-Azizy. Maka judul yang saya ambil adalah Karakter Tokoh pada Novel Di Bawah langit Karya Opick „Tombo Atie dan Taufiqurrahman al-Azizy.

Penulis mengangkat novel $D i$ Bawah langit Karya Opick „Tombo Atie dan Taufiqurrahman al-Azizy sebagai objek penelitian karena novel ini cetakan 1 edisi tahun 2010 isi novel tersebut banyak mengandung nilai-nilai spiritual dan kasih sayang seorang Kyai kepada anak angkatnya.

\section{Metode penelitian}

Metode penelitian yang digunakan dalam mengkaji novel $d i$ Bawah langit karya Opick „Tombo Ati" dan Taufiqurrahman al-Azizy adalah metode kualitatif dengan menggunakan pendekatan deskriptif. 
Metode kualitatif adalah prosedur penelitian yang menghasilkan data deskriptif yang berupa uraian cerita, ungkapan, pernyataan, perkataan, kata yang tertulis dan perilaku yang diamati. Beberapa langkah pengumpulan data yaitu; Studi Pustaka, teknik membaca, dan Teknik mencatat.

\section{Pembahasan}

Para tokoh diklasifikasikan ada dua yaitu;

\section{a. Tokoh Protagonis}

1. Kyai Ahmad

a) Kyai Ahmad memiliki sifat yang sederhana kutipan yang menunjukkan hal tersebut pada novel sebagai berikut.

Di rumah sedarhana, berdinding papan dan anyaman bambu di dekat mushalla itulah, Kyai Ahmad tinggal bersama Maysaroh dan Jaelani (Azizy, 2010: 20)

b) Kyai Ahmad memiliki sifat kasih saying kutipan yang menunjukkan hal tersebut pada novel sebagai berikut.

Kecintaan sang Kyai terhadap isterinya begitu besar, sebab almarhumah tidak hanya semata-mata pendamping hidupnya. Baginya, sang istri adalah gambaran keindahan Allah yang dikaruniakan kepadanya (Azizy, 2010: 19)

c) Kyai memiliki sifat baik hati kutipan yang menunjukkan hal tersebut pada novel sebagai berikut.

Ucapan-ucapannya bagai tetestetes air yang menyejukkan hati masyarakat pantai. Tingkahlaku dan sikapsikapnya selalu santun. Di dusun ini, dialah orang yang paling sabar, pengasih, penolong, pengayom, dan pelindung (Azizy, 2010: 18)

2. Maysaroh memilki sifat yang setia/perhatian kutipan yang menunjukkan hal tersebut pada novel sebagai berikut.

Maka, yang bisa dilakukan Maysaroh hanya menemani, dan terus menemani. Menghibur hati Jaelani. Mengelap kening jaelani yang basah. Menggantikan bajunya yang kotor. Membantunya untuk mengambil air wudhu kala waktu shalat tiba (Azizy, 2010: 244-245)

3. Istri memiliki sifat yang shalihah. Kutipan yang menunjukkan hal tersebut pada novel di bawah ini.

Istri yang shalihah itu menghembuskan nafas terakhir di atas sajadahnya (Azizy, 2010: 18)

4. Jaelani memiliki sifat yang baik hati dan taat. Kutipan yang menunjukkan hal tersebut pada novel sebagai berikut.

Bila dia hidup berumah tangga dengan Maysaroh, maka satusatunya alasan untuk itu karena memenuhi amanah Kyai; memenuhi dawuh Kyai. Kenyataannya, walau sampai saat ini Maysaroh menjadi istrinya, Jaelani tahu bahwa cinta Maysaroh masih suci terhadap Gelung (Azizy, 2010: 127-128)

5. Gelung memiliki sifat yang sakti. Secara lebih rinci, karakter tokoh akan dipaparkan sebagai berikut.

a) Gelung memiliki sifat yang kurang waras/gila. Kutipan yang menunjukkan hal tersebut pada 
novel sebagai berikut.

Gelung sudah seperti orang gila.

Dia berputar-putar, menari-nari mengelilingi api unggun yang dia buat di pantai itu di dekat rumahnya. Kedua tangannya diangkat tinggi-tinggi. Matanya terpejam (Azizy, 2010: 90)

b) Gelung memiliki sifat yang sakti. Kutipan yang menunjukkan hal tersebut pada novel sebagai berikut.

Orang-orang sudah mulai percaya bahwa Gelung itu sakti; bahwa Gelung itu memiliki ilmu yang tinggi (Azizy, 2010: 120)

6. Nelayan/warga memiliki sifat mempercayai Gelung bisa mengetahui sesuatu yang belum terjadi akan terjadi. Kutipan yang menunjukkan hal tersebut pad novel di bawah ini.

Salah seorang nelayan itu mengulangi,"Kami sangat percaya pada Kang Gelung. Kami mau menangkap ikan. Kami harus minta petunjuk pada Kang Gelung" (Azizy, 2010: 135)

7. Sarpo, Bejo, dan Cungkring memiliki karakter yang pemalas dan pantang menyerang dengan keadaan. Kutipan yang menunjukkan hal tersebut pada novel sebagai berikut.

Sarpo, Bejo, dan Cungkring melanjutkan duduknya kembali. Mengisap rokok kembali. Mereka malas untuk melaut ikan-ikan seakan-akan pergi begitu saja. Percuma melaut. Hanya buangbuang bensin saja. Sudah begitu, perahu mereka bisa-bisa ditarik yang punya kalau tak jua mendapatkan ikan (Azizy, 2010: 99)

8. Yusuf memiliki sifat yang cerdas. Kutipan yang menunjukkan hal tersebut pada novel sebagai berikut.

Tak terlihat lagi wajah yusuf dan tingkahnya yang cerdas (Azizy, 2010: 192)

9.

9. Fajar memilki sifat penolong. Kutipan yang menunjukkan hal tersebut pada novel sebagai berikut.

Segera saja Fajar menyerahkan uang tersebut. "Ini ibu, untuk membayar sekolah ibu” (Azizy, 2010: 152)

10. Linggar memiliki sifat yang pemalas. Kutipan yang menunjukkan hal tersebut pada novel di bawah ini

Di pemalas. Hobiny tidur. Saudarasaudaranya sering memanggilnya dengan sebutan "Astuti” Asli Tukang Tidur (Azizy, 2010: 34)

11. Saka memiliki sifat perhitungan. Kutipan yang menunjukkan hal tersebut pada novel di bawah ini.

Dia amat perhitungan. Dia selalu akan membantu saudara- saudaranya asal diberi imbalan yang paling dia sukai adalah makanan (Azizy, 2010: 33-34)

12. Keling memiliki sifat semangat, lucu, dan jujur. Kutipan yang menunjukkan hal tersebut pada novel sebagai berikut.

Tak tampak lagi kelucuan wajah keling dan kekeriboan rambutnya itu (Azizy, 2010: 192)

Keling bersemangat untuk membantu orang berjualan buah- buahan di terminal (Azizy, 2010: 210)

Tetapi dia tahu Keling tidak pernah berbohong. Keling itu tidak pernah membohonginya. Bila Keling mengatakan bahwa Kyai Ahmad meninggal dunia, maka pasti sang Kyai meninggal dunia (Azizy, 2010: 80) 
13. Samudra tidak bermain peran pada novel tersebut.

14. Polisi memiliki sifat tegas. Kutipan yang menunjukkan hal tersebut pada novel sebagai berikut.

Hukum harus ditegakkan. Dan yang bersalah harus dihukum. Beginilah nasib orang kecil, ketahuan bersalah, ditangkap polisi, diadili di penjara (Azizy, 2010: 182)

\section{b. Tokoh Antagonis}

1. Jaelani memiliki sifat pemarah. Kutipan yang menunjukkan hal tersebut pada novel sebagai berikut.

Kemarahan Jaelani sudah sampai pada batas yang seharusnya dia jaga. Kata-katanya sekarang seringkali berubah kasar, sangat keras, berteriak-teriak, melengking-lengking (Azizy, 2010: 140)

2. Gelung memiliki sifat pemarah. Kutipan yang menunjukkan hal tersebut pada novel sebagai berikut.

Jaelani mendinginkan kemarahan Gelung yang sudah seperti api yang berkobar-kobar (Azizy, 2010: 125)

3. Yusuf memiliki sifat pencuri. Kutipan yang menunjukkan hal tersebut pada novel sebagai berikut.

Yusuf melangkah pelan, dari balik tembok, menuju tempat ketiga bapak itu duduk. Ketika dirasakan aman, Yusuf langsung menyambar sejumlah uang dari salah seorang yang tengah berjudi kartu tersebut (Azizy, 2010: 165)

4. Kampret memiliki sifat kasar. Kutipan yang menunjukkan hal tersebut sebagai berikut.

Kepada Bos Kampret itulah Fajar dan adik-adiknya harus memberikan setoran uang. Terkadang ketika anak-anak itu tidak mendapatkan hasil yang banyak, mereka diperlukan kasar oleh Kampret. Terkadang ditendang, ditampar, dan yang lebih sering dicaci-maki. Kasihan mereka, tetapi, mereka tidak bisa berbuat apa-apa.... (Azizy, 2010: 212)

5. Sukma memiliki sifat pemarah.

6. Ibu muda memilki sifat pemarah.

Kutipan yang menunjukkan hal tersebut dalam novel berikut ini. "Hah? Apa? Ikan segini dua puluh lima ribu. Mahal amat?!” ucap ibu muda itu sambil membanting tas plastik berisi ikan tersebut ke atas meja. Ibu muda itu memakik-mekik, "bu, jangan macam-macam ya? Jangan coba-coba mempermainkan harga ikan. Ikan begini saja dua puluh ribu. Yang benar aja! Saya ini pelanggan di sisni ibu ngerti nggak sih??" (Azizy, 2010: 166)

Ada dua cara menggambarkan watak tokoh, yaitu secara langsung (telling analitik) dan tak langsung (showing dramatik).

\section{Analitik}

Kutipan yang menunjukkan hal tersebut pada novel sebagai berikut. Linggar gadis kecil yang cantik. Dia keturunan cina. Dia pemalas. Hobinya tidur. Saudara-saudaranya sering memanggilnya dengan sebutan "Astuti" Asli Tukang Tidur (Azizy, 2010: 34).

Kutipan di atas, menunjukkan Linggar memilki sifat yang pemalas. Watak tokohnya bersifat analitik karena pengarang langsung memaparkan watak atau karakter tokoh, pengarang dengan langsung menyebutkan bahwa tokoh tersebut memiliki sifat pemalas. 


\section{Dramatik}

Kutipan yang menunjukkan hal tersebut dalam novel sebagai berikut.

Maysyaroh berkata kepadanya,"Mas, sampean" mbok(kamu) ya ngomong sama bapak?" "Soal ngerokoknya itu lho Mas. Banyak sekali. Baru setengah, langsung dibuang, bakar lagi yang baru. Hah, mana batuknya sudah ngigrik begitu."

"Kamu sudah ngomong?" "Sudah."

“Terus?”

"ya seperti biasa dia bilang, "Yo bapak besok berhenti selamanya. Tapi besok lho ya?"Aku kan nggak tega dengar batuknya, Mas"

"kita lihat besok. Kalau misalnya besok bapak masih merokok, nanti Mas yang ngomong" (Azizy, 2010: 78).

Kutipan di atas, Kyai Ahmad memiliki sifat yang keras kepala. Sering sekali Maysaroh menasihati beliau jangan merokok lagi tapi, Kyai masih saja merokok. Beliau bilang nanti saya akan berhenti merokok. Kata-katanya selalu bilang seperti itu tapi, kenyataannya beliau tetap saja merokok, Maysroh memceritakan kepada Jaelani. Watak tokohnya bersifat dramatik karena pengarang tidak langsung memaparkan watak atau karakter tokoh, pengarang dengan tidak langsung menyebutkan bahwa tokoh tersebut memiliki sifat keras kepala.

\section{Simpulan dan Saran}

\section{Simpulan}

Karakter tokoh adalah menggambarkan sikap seseorang yang akan diperankan dalam sebuah cerita bisa berupa cerpen, novel, drama, pemain senetron, dan lainlain.

Berdasarkan hasil penelitian yang telah dipaparkan, dapat disimpulkan bahwa tokoh-tokoh yang terdapat pada novel "Di Bawah Langit” karya Opick „Tombo Ati" dan Taufiqurrahman al-Azizy berjumlah 18 orang. Para tokoh diklasifikasikan menjadi dua kategori yaitu tokoh protagonis dan tokoh antagonis. Karakter para tokoh akan dipaparkan sebagai berikut (1) Kyai Ahmad memilki karakter yang penyayang, baik hati, dan sederhana. (2) Masyaroh memilki karakter yang setia/perhatian pada suaminya. (3) Jaelani memiliki karakter yang baik hati, taat, dan pemarah. (4) Istri Kyai Ahmad memiliki karakter yang shalihah. (5) Gelung memiliki karakter yang dihormati masyarakat, sakti, gila/tidak waras, dan pemarah. (6) Nelayan memiliki karakter percaya dengan Gelung. (7) Yusuf dengan karakternya cerdas dan pencuri. (8) Fajar dengan karakternya yaitu penolong. (9) Linggar dengan karakternya pemalas. (10) Saka dengan karakternya perhitungan dan suka membatu.

(11) Ibu muda dengan karakternya kasar/pemarah. (12) Sukma dengan karakternya pemarah. (13) Kampret dengan karakternya kasar/pemarah.

(14) Keling dengan karakternya semangat dan lucu. (15) Polisi dengan karakternya tegas dan menaati peraturan. (16) Sarpo, Bejo, dan Cungkring mereka memiliki karakter yang sama yaitu pemalas dan pantang 
menyerah/putus asa dalam melakukan pekerjaan. Pandangan yang menggambarkan watak tokoh ada dau cara yaitu, secara analitik dan dramatik.Saran

Berdasarkan simpulan di atas penelitian ini masih meneliti hal yang kecil pada novel ini. Kepada peneliti disarankan untuk meneliti Nilai-Nilai Islami dan Cinta Kasih pada novel "Di Bawah Langit" karya Opick „Tombo Atie dan Taufiqurrahman alAzizy. Hasil penelitian ini diharapkan bisa dijadikan sebagai reperensi di sekolah, terutama materi yang berhubungan dengan sastra.

\section{Daftar Rujukan}

Juanda, Asep dan Kaka Rosdyanto. 2006. Intisari Bahasa dan Sastra Indonesia Edisi Revisi. Bandung: CV Pustaka Setia.

Kosasih. 2003. Ketatabahasaan dan Kesustraan, Cermat Berbahasa Indonesia. Bandung: Yrama Widya.

Minderop, Albertine. 2013. Psikologi Sastra, Karya Sastra Metode, Teori, dan Contoh Kasus. Jakarta: Yayasan

Pustaka Obor Indonesia.

Munir, Abdullah. 2010. Pendidikan Karakter. Yogyakarta: PT Pustaka Insan Madani, Anggota IKAPI.

Mustari, Mohamad. 2011. Nilai Karakter: Refleksi untuk Pendidikan Karakter. Yogyakarta: laksBang Pressindo. Suharianto, S. 1983. Dasar-dasar Teori Sastra. Surakarta: Widya Duta.

Wirajaya dan Sudarmawati. 2008. Berbahasa dan Bersastra Indonesia. Jakarta: CV Global Media Grafika.

Wiyatmi. 2006. Pengantar Kajian Sastra. Yogyakarta: Pustaka. 